\title{
Strategies to Promote Improved Construction Practices in Building Construction Industry: A Case Study of Building Contractors in Nsukka LGA of Enugu State
}

\author{
Okanya Arinzechukwu Victor, Daniel Uchenna Chukwu* , Ojo Samson Abayomi \\ Department of Industrial Technical Education, University Of Nigeria, Nsukka, Nigeria \\ Email address: \\ arinze.okanya@unn.edu.ng (O. A. Victor), chukwu.daniel@unn.edu.ng (D. U. Chukwu), samson.ojo@unn.edu.ng (O. S. Abayomi) \\ ${ }^{*}$ Corresponding author
}

\section{To cite this article:}

Okanya Arinzechukwu Victor, Daniel Uchenna Chukwu, Ojo Samson Abayomi. Strategies to Promote Improved Construction Practices in Building Construction Industry: A Case Study of Building Contractors in Nsukka LGA of Enugu State. International Journal of Vocational Education and Training Research. Vol. 5, No. 2, 2019, pp. 53-58. doi: 10.11648/j.ijvetr.20190502.13

Received: September 4, 2019; Accepted: September 27, 2019; Published: October 31, 2019

\begin{abstract}
This study sought to determine the strategies to promote improved construction practices in building construction industry. A case study research design was adopted for the study. The study was carried out in Nsukka Local Government Area of Enugu State. The population for this study was 92, consisting of 54 general foremen and 38 site engineers in Nsukka. No sampling was done for this study since the total population of 92 subjects is of manageable size. Structured Questionnaire was used as instrument for data collection. Data collected were analyzed using the mean and standard deviation for the research questions. Cronbach alpha reliability coefficient of 0.972 was obtained for the internal consistency of the instrument. Based on the data analyzed, the study identified strategies to promote improved construction practices in building construction industry. The study therefore recommended the following: The federal and state ministry of housing should enact laws which make it mandatory for contractors to embark on annual training, retraining and in-service training to learn advanced and improved practices in building technology. The identified strategies to promote improved construction practices in building construction industry should be included into the school curriculum of building construction of technical colleges and other higher institutions that teach building technology as a course of study. Inclusion of the identified strategies into the curriculum will benefit the students and graduates hence it will prepare and equip them with improved knowledge of construction practices in building technology.
\end{abstract}

Keywords: Building Construction Industry, Building Contractors, Construction Practices, Construction Safety Practices, Organizational Practices

\section{Introduction}

The need to promote improved construction practices in the building industries worldwide has become a topical issue. The complexity of building construction projects and the continuous demand for improved and efficient project delivery have put pressure on building contractors, creating a lot of management challenges that require high sense of construction strategies, and management acumen for construction managers and builders. Cinelli et al. [1] noted that people are becoming increasingly aware that the quality of building design, manner of construction and operation of buildings are key factors that influence the implementation of sustainable development in the building construction industry.

Building construction refers to the technical processes and methods used in the creation of buildings. Building construction involves technical design and expertise used in the application and integration of construction technologies in the building design process. In other words, it is the ability to analyze, synthesize and evaluate building design factors in order to produce efficient and effective technical design solutions which satisfy performance, production and procurement criteria [2]. Erecting a building requires the collaborative work of client, consultants, suppliers, contractors and sub-contractors to properly prepare planning 
applications, building regulations submissions, construction documentation, operation and maintenance manuals and so on. Building construction incorporate materials leveraging on best applications, physical properties, capacities and vulnerabilities, the functioning of components and systems, the principles, procedures and details of building assembly and operating strategies [3]. Ashworth, Hogg and Higgs [4] stated that building construction industries comprises of all construction firms or companies which specialize in building houses for clients on contract bases. The building construction industry is made of groups of builders and contractors who are contracted by clients or people to make buildings for them [3]. Building being a product of interrelated systems and assemblies working together to contribute to its proper functioning, requires proper assemblage and coordination. The one who ensure proper coordination of activities to achieve the specified functions is the contractor.

A building contractor is the person/firm known to have agreed to execute a building project based on agreed considerations (finance). The building contractor's responsibilities include: applying for building permits, advisory role, securing the property, providing temporary utilities on site, managing personnel on site, providing site surveying and engineering, disposing or recycling of construction waste, monitoring schedules and cash flows, and maintaining accurate records. The contractor often hires specialized subcontractors to perform all or portions of the construction work and should ensure everyone follows the construction practices [3].

Construction practices are those standard guidelines which building contractors are expected to follow while carrying out building construction projects for their clients [5]. A complex process involving the selection of standard building systems, adaptation and integration, to produce a building that meets the client's needs within the limitations of government regulations and market standards are integrate part of construction practices [6]. Construction practices cut across a number of stages based on intended building type including: planning practices, organizational practices, construction safety practices and evaluation practices [6].

Planning practices in building construction helps the builders to determine the materials, staff and machines needed for the project. It also helps in determining other necessary details required in carrying out building construction. Proper planning helps the contractor to delegate tasks accordingly to all the workmen in the building construction industry [7]. Proper planning practices helps in on-time completion of work, reduces incidents of accidents or mistake, reduces both human and material waste on site and improves general management of resources on site. The adoption of proper planning practices by the contractor leads to good organizational practices in building construction.

Organizing is the management function that usually follows after planning. Alexander, [8] opined that organizational practices involves the structuring, integrating, coordinating task goals, and activities to resources in order to attain given objectives on site. An organized practice in building construction improves the safety practices on site as it will reduce accidents or any other form of demise or ruin. Safety is the condition of being protected from harm or other non-desirable outcomes [9]. It is pertinent for builders to recognize and emphasize on safety practices before and during the construction processes of a building. Imbibing safety practices, ensuring that the code of building ethics is met reduces site accidents, manages costs and reduces wastage of resources during building construction. Equally important is the need for evaluation of work progresses during construction [10].

Evaluation practice helps the builders to ascertain the extent to which the work was done in accordance to design specifications. According to Alexander [8], the aim of evaluation in building construction is to determine the relevance and fulfillment of objectives, efficiency, effectiveness, impact and sustainability, as set out in the building plan and specification. Strom, et al. [11] also noted that builders are able to effectively improve on the planning, supervision, organization, and execution of projects by adopting proactive evaluation practices during building construction. Therefore, the researchers seek to find out these strategies which will help to promote improved construction practices in building construction industry.

\subsection{Statement of the Problem}

Construction involves series of operations that require the use of complex materials, tools and machines. These resources coupled with the work environment often create accident-prone situations. According to Kado [12], harsh weather, poor soil composition which affects the foundation laying of buildings, irregular landscape for building constructions, inadequate source of building materials such as sand and cement, and importation of sub-standard reinforcements are some of the challenges facing building construction industries, of which the construction managers must proffer solutions. More so, there are issues of poor construction practices leading to building collapses, building failures and other destructive effects associated with poor construction practices in Nigeria. As a result of poor construction practices, building construction is reported to kill more persons more than any other industry after mining [5]. In addition to poor attention to safety and many construction challenges, construction projects often suffer from underperformance in terms of time delays, cost overruns, disruptions, quality defects among others. The case is not different in Nsukka Urban, a developing city in Enugu State, Nigeria.

For instance, a report by Okoro [13] shows a section of 'Original Lodge' building under construction at AmofiaOdenigwe Village, a suburb of Nsukka which collapsed as a result of poor planning and lack of adequate monitoring of the entire building process by the Site Engineer. Prior to this, a two storey building was reported to have collapsed at "Ogurugu Road" near Onuiyi Junction, Nsukka. A private investigation carried out by Uja [14] shows that the 
contractor overlooked the reprimands by Nsukka Urban Town Planning Commission about erecting the building at the said site. Furthermore, on July 08, 2015, Uja [14] reported the collapse of a three-storey structure at "Hilltop area", an off-campus close to the University of Nigeria, Nsukka. Subsequent investigations into these building collapses showed a common trend of the use of substandard materials such as cements, inadequate adherence to specified reinforcements, poor or no monitoring/supervision among others [13, 14]. Moreover, owners of the said structures asserted issues of lag in delivery time when resources were duly supplied to the contractors, cost overruns above schedule as well as safety violations leading to more accident records. In seeking remedy to the incessant incidents of building collapses in Nsukka Urban, it is pertinent to determine strategies to promote improved construction practices in building construction industry, to sustain the development of the city and foster investors' confidence on indigenous companies, hence the need for this research.

\subsection{Research Questions}

This research seeks to provide answers to the following questions:

1. What are the strategies for promoting improved planning practices of building contractors?

2. What are the strategies for promoting improved organizational practices of building contractors?

3. What are the strategies for promoting improved construction safety practices of the building contractors?

4. What are the strategies for promoting improved evaluation practices of the building contractors?

\section{Methodology}

The study adopted a case study survey design. The study was carried out in Nsukka Local Government Area of Enugu
State, Nigeria. Enugu State is in the South East Geo-political Zone of Nigeria. There are 17 local government areas of Enugu State. The local government areas include: Aninri, Awgu, Enugu East, Enugu North, Enugu South, Ezeagu, Igbo Etiti, Igbo Eze North, Igbo Eze South and Isi Uzo. Others are, Nkanu East, Nkanu West, Nsukka, Orji River, Udenu, Udi and Uzo-Uwani. Among these LGAs, the state capital spans across Enugu North, Enugu South and Enugu East. Nsukka LGA is however notable as one of the cities in Enugu State [15]. A reputation attained partly as one of the major centres of commerce in the 1950s and as a home of the prestigious University of Nigeria, Nsukka; therefore the suitability of this area for the study. The population for this study was 92, consisting of 54 General Foremen and 38 Site Engineers in the registered construction industries in Nsukka. No sampling was used for this study since the total population of 92 subjects is of manageable size.

The instrument for data collection was a structured 30 item questionnaire developed from literature in order to obtain the data for the study. The questionnaire was designed based on four point scale of Strongly Agree (SA), Agree (A), Disagree (D) and Strongly Disagree (SD) with assigned weights of 4, 3,2 , and 1 respectively. The instrument was face validated and tested for reliability using Cronbach Alpha. The overall reliability of the instrument showed 0.972. Data collected were analyzed using descriptive statistics. Mean was used to answer the research questions. Any item of the questionnaire with mean of 3.50 and above was considered to be agreed; while any item of the questionnaire with mean value below 3.50 was considered to be disagreed.

\section{Results}

Research Question 1: What are the strategies for promoting improved organizational practices of building contractors?

\begin{tabular}{|c|c|c|c|c|}
\hline \multicolumn{5}{|c|}{$\mathbf{N}=92$} \\
\hline $\mathbf{S} / \mathbf{N}$ & Item Statements & $\mathbf{X}$ & SD & Remarks \\
\hline 1 & Preparing the building plans in line with the town planning and housing codes of the area. & 4.38 & 0.82 & Agreed \\
\hline 2 & Getting a building permit or an approval from the town planning commission of the area. & 3.95 & 0.86 & Agreed \\
\hline 3 & Recruiting and Involving qualified, experienced workers and craftsmen for the building construction & 4.04 & 1.09 & Agreed \\
\hline 4 & $\begin{array}{l}\text { Defining and assigning roles, and responsibilities to the workers and lay down strategies on how the activities } \\
\text { should be carried out during building construction. }\end{array}$ & 4.52 & 0.54 & Agreed \\
\hline 5 & $\begin{array}{l}\text { Analyzing the project network or models to determine project duration and identifying critical and non-critical } \\
\text { activities. }\end{array}$ & 4.46 & 0.50 & Agreed \\
\hline 6 & Forecasting the project budget allocations for achieving targets assigned to each organizational unit. & 3.96 & 0.86 & Agreed \\
\hline 7 & $\begin{array}{l}\text { Establishing standards for planning and controlling workers, materials, equipment, costs and income of each } \\
\text { work package. }\end{array}$ & 3.83 & 1.28 & Agreed \\
\hline 8 & $\begin{array}{l}\text { Distinguish between the skilled and unskilled workers to improve the construction management skill of the } \\
\text { contractor }\end{array}$ & 4.10 & 1.01 & Agreed \\
\hline 9 & Testing the soil before embarking on any building construction & 4.04 & 1.09 & Agreed \\
\hline
\end{tabular}

$\mathrm{X}=$ Mean SD $=$ Standard Deviation.

The data presented in Table 1 revealed that the 10 items have their mean value ranging from 3.83 to 4.95 . This shows that the mean value of each item was above the cut-off point of 3.50 , indicating that 10 items are agreed as strategies for 
promoting improved organizational practices of building contractors.

Research Question 2: What are the strategies for promoting improved organizational practices of building contractors? The data for answering research question 2 are presented in Table 2.

Table 2. Mean and Standard Deviation of Respondent's Responses on the strategies for promoting improved organizational practices of building contractors.

\begin{tabular}{|c|c|c|c|c|}
\hline \multicolumn{5}{|c|}{$\mathrm{N}=92$} \\
\hline $\mathbf{S} / \mathbf{N}$ & Item Statements & $\mathbf{X}$ & SD & Remarks \\
\hline 11 & $\begin{array}{l}\text { Organizing and briefing the whole workforce/workers on the details of the work before, during and after the project } \\
\text { work. }\end{array}$ & 3.73 & 1.16 & Agreed \\
\hline 12 & Mapping out and locating plant and machine layouts for efficient site layout. & 4.67 & 0.47 & Agreed \\
\hline 13 & Providing exact storage position for the main equipment and other construction tools in the site. & 3.82 & 0.99 & Agreed \\
\hline 14 & Designing and providing temporary offices in the construction site. & 4.03 & 1.13 & Agreed \\
\hline 15 & Designing and providing parking lots for goods, tools and equipment which are used on site. & 3.97 & 1.06 & Agreed \\
\hline 16 & Designing and providing surface water drainage system in the site and in the building construction. & 3.17 & 1.08 & Disagreed \\
\hline
\end{tabular}

$\mathrm{X}=$ Mean $\mathrm{SD}=$ Standard Deviation .

The data presented in Table 2 revealed that only one item have a mean value less than 3.50 while five items have their mean value ranging from 3.73 to 4.67 . The table shows that five items were agreed upon as strategies for promoting improved organizational practices of building contractors.
Research Question 3: What are the strategies for promoting improved construction safety practices of the building contractors? The data for answering research question 3 are presented in Table 3.

Table 3. Mean and Standard Deviations of respondent's responses on the strategies for promoting improved construction safety practices of the building contractors.

\begin{tabular}{|c|c|c|c|c|}
\hline \multicolumn{5}{|c|}{$\mathbf{N}=92$} \\
\hline $\mathbf{S} / \mathbf{N}$ & Item Statements & $\mathbf{X}$ & SD & Remarks \\
\hline 17 & $\begin{array}{l}\text { Providing health and safety warning signs on site to create awareness to the workers on the need for safety practices } \\
\text { as they carry out their work. }\end{array}$ & 3.93 & 0.92 & Agreed \\
\hline 18 & Providing first aid box, fire extinguishers and installing other safety devices on construction site. & 3.59 & 1.11 & Agreed \\
\hline 19 & $\begin{array}{l}\text { Promoting and encouraging safety practices of workers by providing safety helmets, strong boots, overall etc, to all } \\
\text { workers to avoid/reduce injuries on site. }\end{array}$ & 4.76 & 0.43 & Agreed \\
\hline 20 & $\begin{array}{l}\text { Ensuring that the ladders, scaffolding and other support structures on site is strong enough to hold the weight they } \\
\text { were meant to carry. }\end{array}$ & 4.24 & 0.43 & Agreed \\
\hline 21 & Frequent enlightenment of workers on safety procedures and practices during building construction. & 4.49 & 0.50 & Agreed \\
\hline 22 & Synthetic and natural rope used in suspension scaffolding must be protected from heat-producing sources. & 4.76 & 0.43 & Agreed \\
\hline 23 & $\begin{array}{l}\text { Ensuring that electrical wiring methods and design are safe enough and meet up with safety guidelines and } \\
\text { specifications. }\end{array}$ & 3.83 & 0.77 & Agreed \\
\hline
\end{tabular}

$\mathrm{X}=$ Mean $\mathrm{SD}=$ Standard Deviation.

The data presented in Table 3 revealed that all the 7 items have mean values ranging from 3.59 to 4.76 . This showed that the mean values of each item was above the cut-off point of 3.50, indicating that all the 7 items were agreed as strategies for promoting improved construction safety practices of the building contractors.

Research Question 4: What are the strategies for promoting improved evaluation practices of the building contractors? The data for answering research question 4 are presented in Table 4.

Table 4. Mean and Standard Deviations of respondent's responses on the strategies for promoting improved evaluation practices of the building contractors.

\begin{tabular}{|c|c|c|c|c|}
\hline \multicolumn{5}{|c|}{$\mathbf{N}=\mathbf{9 2}$} \\
\hline $\mathbf{S} / \mathbf{N}$ & Item Statements & $\mathbf{X}$ & SD & Remarks \\
\hline 24 & Keeping Internal records to track project activities, processes and output indicators. & 4.29 & 0.82 & Agreed \\
\hline 25 & $\begin{array}{l}\text { Ensuring the improvement in accountability of key stakeholders such as the quantity surveyors and site supervisor } \\
\text { in the work. }\end{array}$ & 4.65 & 0.48 & Agreed \\
\hline 26 & $\begin{array}{l}\text { Keeping records of relevant secondary information to track changes in outcomes and impacts and accompany } \\
\text { internal records, such as policy changes, media coverage, relevant surveys/databases. }\end{array}$ & 3.90 & 1.23 & Agreed \\
\hline 27 & $\begin{array}{l}\text { Attending Periodic group workshops, discussions, focus groups (including group ratings/ranking exercises and/or } \\
\text { other visual techniques such as time lines, mapping, diagrams; other diagnostic tools). }\end{array}$ & 4.52 & 0.54 & Agreed \\
\hline 28 & Carrying out periodic surveys to assess attitudes, event feedbacks and/or behaviour change among the workers. & 3.59 & 0.59 & Agreed \\
\hline 29 & $\begin{array}{l}\text { Ensure that the level of site security (general visibility from interstate, perimeter fence, controlled access, etc.) is } \\
\text { adequate. }\end{array}$ & 3.44 & 1.19 & Disagreed \\
\hline 30 & Finding out, Preventing and working against poor team planning. & 3.42 & 0.75 & Disagreed \\
\hline
\end{tabular}

$\mathrm{X}=$ Mean $\mathrm{SD}=$ Standard Deviation.

The data presented in Table 4 revealed that 2 items were disagreed upon as their mean values were below 3.50. The other 5 items have their mean value above the 3.50 cut off. It shows that 5 items were agreed upon by the respondents as 
the strategies for promoting improved evaluation practices of the building contractors.

\section{Discussion of Findings}

The findings from Table 1 indicate that strategies for promoting improved planning practices of building contractors include: establishing standards for planning and controlling workers, materials, equipment, costs and income of each work package; engaging the services of a skilled site supervisor who can develop a healthy rapport with the workers under him/her, ensuring that the building plans are in compliance with and correct specifications with the taste of the client, and forecasting input resources, production costs and the value of the work done. The findings are in line with the opinion of Chudley \& Greeno, [5] who stated that ability of the contractor to effectively map out plans for construction practices helps to improve efficiency in the construction industry. Barnbara [6] also found that the ability to attend training and seminars for professional bodies and cooperating with the local town planning authority also can help to improve construction practices of building contractors.

The findings from Table 2 shows that the strategies for promoting improved organizational practices of building contractors include: organizing and briefing the whole workforce/workers on the details of the work before, during and after the project work, mapping out and locating plant and machine layouts for efficient site layout, providing exact storage position for the main equipment and other construction tools in the site, designing and providing temporary offices in the construction site and designing and providing parking lots for goods, tools and equipment which are used on site. These findings are in line with Shofoluwe et al. [16] who stated that the ability of the builder to design site layout and assign jobs and operational activities to workers are part of the activities for improving the organizational skills of contractors in major cities. The findings are also in consonance with the findings of Kumaraswamy \& Chan, [17] in that it is of great importance that an adequate period before starting site operation is made available for organization and coordination of equipment and methods. The author added that the ability to galvanize and coordinate work activities on site improve the organizational practices of building contractors.

In Table 3, the strategies for promoting improved construction safety practices of the building contractors were found to include: providing first aid box, fire extinguishers and installing other safety devices on construction site; promoting and encouraging safety practices of workers by providing safety helmets, strong boots, overall etc. to all workers to avoid/reduce injuries on site, as well as frequent enlightenment of workers on safety procedures and practices during building construction. This is in line with Kumaraswamy \& Chan, [17] who stated that monitoring poor attitude and bad construction practices of workers to prevent unforeseen occurrences as a result of carelessness helps to improve the safety in building technology. Tunji and Olosoji [18] stated that ensuring the use of quality building materials and use of standard materials improves the site supervision skills of building contractors.

The findings from Table 4 indicate that strategies for promoting improved evaluation practices of the building contractors include: keeping internal records to track project activities, processes and output indicators; keeping records of relevant secondary information to track changes in outcomes and impacts and accompany internal records, such as policy changes, media coverage, relevant surveys/databases and carrying out periodic surveys to assess attitudes, event feedbacks and/or behaviour change among the workers. This is in line with Barnbara [6] who stated that keeping records of relevant secondary information of building projects guides contractors in executing better jobs and improves construction practices of building contractors.

\section{Conclusions}

The study was carried out to ascertain the strategies for promoting improved construction practices in building technology in Nsukka LGA of Enugu State. The study, based on descriptive survey design, was guided by four research questions addressing the specific purposes of the study. The purposes include determining: strategies for promoting improved planning practices of building contractors; strategies for promoting improved organizational practices of building contractors; strategies for promoting improved construction safety practices of the building contractors and strategies for promoting improved evaluation practices of the building contractors.

The findings of the study identified some strategies for promoting improved planning practices of building contractors to include: obtaining the right of occupancy for the site of the building construction; preparing the building plans in line with the town planning and housing codes of the area; and recruiting and involving qualified experienced workers and craftsmen for the building construction. Also, for promoting improved organizational practices of building contractors; ensuring that topographical survey and contours of the site is effectively carried out before the actual building construction, designing and providing temporary offices, parking lots for goods, tools and equipment which are used on site and organizing and briefing the whole workforce/workers on the details of the work before, during and after the project work.

Furthermore, this study also identified some strategies for promoting improved construction safety practices of the building contractors to include: providing health and safety warning signs on site to create awareness to the workers on the need for safety practices as they carry out their work; providing first aid box, fire extinguishers and installing other safety devices on construction site and promoting and encouraging safety practices of workers by providing safety helmets, strong boots, overall etc, to all workers to avoid/reduce injuries on site. 


\section{Recommendations}

Based on the findings of the study, the following recommendations were made:

1. The federal and state ministry of housing should enact a law which makes it mandatory for contractors to embark on annual training, retraining and in-service training to learn advanced, and improved construction practices in building technology.

2. The government through the state and federal ministry of housing should set up task force group which will monitor the activities of building contractors to ensure that they follow standard practices while carrying out any building construction project.

3. The identified strategies for promoting improved construction practices in building technology should be included into the school curriculum of building construction of technical colleges and other higher institutions that teach building technology as a course of study. Inclusion of the identified strategies into the curriculum will benefit the students and graduates. It will prepare and enable them to have an improved knowledge of construction practices in building technology.

\section{References}

[1] Cinelli M, Coles SR and Kirwan K (2015). Analysis of the potentials of multi criteria decision analysis methods to conduct sustainability assessment. Ecological Indicators, 46, 138-148, http://doi.org/10. 1016/j.ecolind.2014.06.011.

[2] Sullivan, L. O, (2014). Building Technology Education Program. Accessed from lizosullivanaia. Wordpress.com.

[3] Allen, Edward, \& Iano Joseph (2009). Fundamentals of Building Construction Materials and Methods. 5th ed. Hoboken, N. J.: John Wiley \& Sons. Retrieved from https://en.wikipedia.org/wiki/General_contractor.

[4] Ashworth, A., Hogg, K., \& Higgs, C. (2016). Willis's practice and procedure for the quantity surveyor. John Wiley \& Sons.

[5] Chudley, R, \& Greeno, R. (2016). Advanced Construction Technology. Harlow; New York: Pearson Prentice Hall.

[6] Barnbara J. Jackson (2010). Construction Management Jump Start, 2nd ed. Indiana. Wiley Publishing Inc.
[7] Arditi, D., and Lee, D. E. (2017). Service quality performance of design/build contractors using quality function deployment. Construction Management and Economics, 22 (1), 123-127.

[8] Alexander, O. (2008). Quality Assurance, Quality Plan and Quality Control manual: FITZAN Ltd Turnkey Site Builders Civil and Maintenance.

[9] Charles G. Oakes, PhD, Blue Ember Technologies, LLC. Safety versus Security in Fire Protection Planning Archived 2012-03-13 at the Wayback Machine, The American Institute of Architects: Knowledge Communities, May 2009. https://en.wikipedia.org/wiki/Safety\#Meanings.

[10] Ghanem, A. A., AbdelRazig, Y. A. \& Mahdi, S. M. (n. d.). Evaluation of a real-time construction project progress tracking. Retrieved from http://www.irbnet.de/daten/iconda/CIB4432.pdf.

[11] Strom, S., Nathan, K. and Wolan, J. (2018) Site Engineering for Landscape Architects, 6th Edition. John Wiley and Sons.

[12] Kado, D. (2011). Assessment of Quality Management practices of The Nigerian Building Design Firms (Published Doctoral Thesis). Department of Building Ahmadu Bello University, Zaria.

[13] Okoro, P. (2017). Quality Improvement Tools and Techniques. Hill Books, Enugu State.

[14] Uja, M. (2016). Client Satisfaction and Quality Management Systems in Contractor Organisations. Prime Press, Nnewi.

[15] Edmund Amuezuoke Iyi, E. A. (2014). A Review of Enugu (Enugu State, Nigeria) urban growth and development. Journal of Research in Environmental and Earth Science, 1 (3), 44-5.

[16] Shofoluwe, M, Ofori-Boadu, A, Waller, L, Bock-Hyeng, C. (2013) 'Quality Improvement Practices of Award-Winning Residential Builders and Housing Developments', International Journal of Industrial Engineering \& Production Research., Vol. 23, Number 1, pp, 7-12.

[17] Kumaraswamy, M. M. \& Chan, D. W. M. (2016). Factors facilitating faster construction. Journal of Construction Procurement, 5 (2), 88-98.

[18] Tunji Olayeni, Patience, A \& Timothy Olasoji, (2014). Evaluating Construction Project Performance: A case study of SMEs in Lagos Nigeria. Covenant University, Ota, Ogun State. 